\title{
Dynamics of Ascospore Maturation and Discharge in Erysiphe necator, the Causal Agent of Grape Powdery Mildew
}

\author{
Vittorio Rossi, Tito Caffi, and Sara E. Legler
}

Istituto di Entomologia e Patologia vegetale, Università Cattolica del Sacro Cuore, 29122 Piacenza, Italy. Accepted for publication 14 August 2010.

\begin{abstract}
Rossi, V., Caffi, T., and Legler, S. E. 2010. Dynamics of ascospore maturation and discharge in Erysiphe necator, the causal agent of grape powdery mildew. Phytopathology 100:1321-1329.

Dynamics of ascocarp development, ascospore maturation, and dispersal in Erysiphe necator were studied over a 4-year period, from the time of ascocarp formation to the end of the ascosporic season at the end of June in the following spring. Naturally dispersed chasmothecia were collected from mid-August to late November (when leaf fall was complete); the different collections were used to form three to five cohorts of chasmothecia per year, with each cohort containing ascocarps formed in different periods. Chasmothecia were exposed to natural conditions in a vineyard and periodically sampled. Ascocarps were categorized as containing mature or immature ascospores, or as empty; mature ascospores inside chasmothecia were enumerated starting from late February. Ascospore discharge was determined using silicone-coated slides that were placed 3 to $4 \mathrm{~cm}$ from sections of the vine trunk holding the chasmothecia. Before complete leaf fall, $34 \%$ of the chasmothecia had mature ascospores, $48 \%$ had immature ascospores, and $18 \%$ were

empty; in the same period, the trapped ascospores represented $56 \%$ of the total ascospores trapped in an ascosporic season (i.e., from late summer until the next spring or early summer). The number of viable chasmothecia diminished over time; 11 and 5\% of chasmothecia had mature ascospores between complete leaf fall and bud break and after bud break, respectively. These ascocarps discharged $\approx 2$ and $42 \%$ of the total ascospores, respectively. All the ascocarp cohorts released ascospores in autumn, survived the winter, and discharged viable ascospores in spring; neither ascospore numbers nor their pattern of temporal release was influenced by the time when chasmothecia were collected and exposed in the vineyard. Abundance of mature ascospores in chasmothecia was expressed as a function of degree-days (DD) (base $10^{\circ} \mathrm{C}$ ) accumulated before and after bud break through a Gompertz equation $\left(R^{2}=0.92\right)$. Based on this equation, $90 \%$ of the ascospores were mature when 153 DD (confidence interval, 100 to $210 \mathrm{DD}$ ) had accumulated after bud break. Most ascospores were trapped in periods with $>2 \mathrm{~mm}$ of rain; however, a few ascospores were airborne with $<2 \mathrm{~mm}$ of rain and, occasionally, in wet periods of $\geq 3.5 \mathrm{~h}$ not initiated by rain.
\end{abstract}

Erysiphe necator Schwein (syn. Uncinula necator), the causal agent of powdery mildew of grape (Vitis vinifera L.), is a heterothallic fungus $(3,42,44)$. Once initiated, the chasmothecia mature in several stages: initially they are white, then yellow, then brown, and finally they become black at maturity. During maturation, chasmothecia are fixed to the powdery mildew colony by anchorage hyphae. When chasmothecia are morphologically mature, characteristic appendages appear, the anchorage breaks down, and the fruiting bodies are dispersed by splashing rain $(10,16)$. Rain deposits the chasmothecia onto the bark of the vine trunk, the soil, or leaf litter on the soil surface. Ascocarp survival, however, is consistently higher in exfoliating bark than on the other substrates (16). Ascospores are repeatedly released mainly between budbreak and blooming of the grapevine (39), and cause primary infections on leaves (18). Primary infections trigger powdery mildew epidemics, which are then driven by the asexual infection cycles (7).

Despite an initial controversy about the importance of the ascospores as a consistent source of primary inoculum for powdery mildew disease on grapevine, ascospores are now considered an important form of primary inoculum, either alone or in combination with mycelia in the dormant buds, depending on the viticultural region $(9,14,16,26,28,30,34,39,43,45)$.

Several aspects of the sexual stage of E. necator have been elucidated but some aspects remain unclear. These include the

Corresponding author: V. Rossi; E-mail address: vittorio.rossi@ unicatt.it

doi:10.1094/PHYTO-05-10-0149

(c) 2010 The American Phytopathological Society relationship between timing of chasmothecia development and ascospore release during the following season, the significance of late-season ascospore release, and the effect of vineyard environment on chasmothecia development and ascospore release. Chasmothecia develop and disperse for some weeks late in the vinegrowing season $(10,16)$ and, in Northern Italy, ascocarps were repeatedly dispersed from mid-August to the end of leaf fall in mid-November (40). As a consequence, chasmothecia have different dates of initiation and periods of development. Research with Podosphaera mors-uvae (syn. Sphaerotheca mors-uvae), the causal agent of powdery mildew of Ribes nigrum L. (blackcurrant), suggests that timing of ascocarp initiation and development could influence the timing of ascopore release in the following spring (29). For E. necator, however, no information is available on how the timing of chasmothecia initiation affects their development, overwintering, and ascospore discharge in the next season. Although dispersal of ascospores between bud break and blooming of the grapevine has been widely documented $(13,20,21,31,39)$, some ascospores have also been found in the vineyard air in autumn $(4,39)$. The significance of the late-season dispersal of ascospores has not been sufficiently investigated, and its role in the powdery mildew epidemiology has not been discussed. Environmental factors that determine the rate of ascospore maturation, ascocarp dehiscence, and ascospore release have been investigated under environmentally controlled conditions $(17,24,30)$, but only a few studies have dealt with the environmental effects in the vineyard $(31,39)$.

The objective of this work was to investigate the dynamics of ascocarp development, ascospore maturation, and ascopore dispersal in E. necator from the time of ascocarp formation to the 
end of the ascosporic season in the next spring. The research also determined the effect of environmental factors on these dynamics and the effect of chasmothecia age on ascospore maturation and dispersal.

\section{MATERIALS AND METHODS}

Collection and processing of chasmothecia. From 2005 to 2008, chasmothecia were collected in commercial vineyards in northern Italy. These vineyards were characterized by different soil types, vine varieties, trellis systems, and cropping regimes. In each vineyard, a plot of at least 10 rows of vines, $100 \mathrm{~m}$ long, was not sprayed against powdery mildew for the entire season. Chasmothecia that had dispersed toward the vine bark were collected from mid-August to complete leaf fall with filter paper funnels as described by Gadoury and Pearson (16). Chasmothecia were not collected from fallen leaves or soil because few of these survive the winter (16). In total, 15 funnels $(13 \mathrm{~cm}$ in diameter) were installed on three randomly selected vines in each vineyard in mid-August: one funnel each was secured to the lower, intermediate, and upper trunk, and two were secured to the permanent cordon. The funnels were oriented so that the wide opening was on top and horizontal. Filter paper disks $(15 \mathrm{~cm}$ in diameter) (Perfecte 2; Cordenons Impressive Paper, Milan, Italy) were fixed to each funnel by pushpins in such a way that any material falling into the funnel top remained on the filter. In midAugust, E. necator colonies were present on leaves and on bunches but no chasmothecia had formed, as indicated by microscopic observation of sample leaves and berries collected at the time of funnel installation. Filters were replaced every 2 weeks until leaf fall was complete in late November; therefore, chasmothecia were collected on seven dates per year. Each filter was examined with a stereomicroscope ( $\times 20$ magnification) and the number of chasmothecia determined. The number of chasmothecia trapped per square centimeter of trap surface was calculated and expressed as the cumulative proportion of the total chasmothecia caught over each season.

The different collections were used to form cohorts of chasmothecia dispersed at different times; three to five cohorts were formed per year, depending on the year (Table 1). A cohort includes the chasmothecia collected over one or two collections. The chasmothecia of each cohort were split into two groups. One group was put into nonwoven polypropylene fabric bags (AGRITNT17; Carreta Snc, Carrè, Vicenza, Italy) and the second group was arranged onto the bark of sections of vine trunk that were $\approx 30 \mathrm{~cm}$ long. Both bags and trunk sections were exposed outside in the experimental vineyard at the University of Piacenza (northern Italy) by placing them on metal nets placed horizontally at $0.5 \mathrm{~m}$ above the soil. The bags were put over a layer of filter paper, while trunks were fixed in such a way that chasmothecia were on the upper side of the trunk. Between collection and exposure, chasmothecia either in bags or on trunks were maintained outdoors but protected from rainfall.

In spring, 50 random plants of the experimental vineyard at the University of Piacenza were visited every 2 to 4 days to determine the timing of beginning of bud break and bloom. A weather station (Vantage Pro2; Davis Instruments Corp., Hayward, CA) located $2 \mathrm{~m}$ from the bags and trunks provided hourly records of temperature, relative humidity, rainfall, and wetness.

Developmental stage of chasmothecia. At 7- to 9-day intervals, beginning from the time when chasmothecia were exposed outside in the year that they formed to late June of the following year, chasmothecia were retrieved from the bagged samples. Twenty chasmothecia per cohort were harvested, crushed on glass slides, examined microscopically, and categorized as (i) containing mature ascospores with vacuolated cytoplasm, (ii) containing immature ascospores with granular cytoplasm, or (iii) empty (i.e., they did not contain asci or ascospores). Degenerated ascospores containing dark cytoplasm were never observed (39). The percentage of chasmothecia in each category was calculated for each cohort and sampling date. Viability of the ascospores was assessed on a subsample of chasmothecia with mature ascospores using the method of Cortesi et al. (10); chasmothecia were considered viable if they contained any viable ascospores (21).

Dynamics of mature ascospores in spring. At 7- to 9-day intervals, beginning from late February (vines with dormant buds) to late June (bloom already finished), 20 chasmothecia were retrieved from the bagged samples. These overwintered ascocarps were crushed on glass slides, placed in $1 \mathrm{ml}$ of water, and shaken vigorously for $3 \mathrm{~min}$; the resulting suspension was examined microscopically and the number of mature ascospores was recorded with a hemacytometer. These numbers were then expressed as a percentage of the total number of mature ascospores found among all cohorts during the entire sampling season.

The cumulative percentage of mature ascospores was regressed over time. Time was expressed in either days or physiological units (33) starting from the time of bud break; physiological units were calculated by accumulating the average daily temperatures

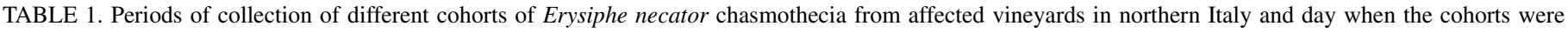
exposed outside to natural conditions

\begin{tabular}{|c|c|c|c|c|}
\hline Year & Period of collection & Chasmothecia $(\%)^{\mathrm{a}}$ & Cohort & Day of exposure \\
\hline \multirow[t]{3}{*}{2005} & 27 August-26 September & 27 & I & 13 October \\
\hline & 27 September-24 October & 55 & II & 4 November \\
\hline & 25 October-7 November & 18 & III & 11 November \\
\hline \multirow[t]{5}{*}{2006} & 3-19 September & 26 & I & 21 September \\
\hline & 20 September-3 October & 39 & II & 6 October \\
\hline & 4-17 October & 7 & III & 20 October \\
\hline & 18-31 October & 20 & IV & 3 November \\
\hline & 1-15 November & 9 & $\mathrm{~V}$ & 17 November \\
\hline \multirow[t]{5}{*}{2007} & 14 August-10 September & $<1$ & I & 27 September \\
\hline & 11-24 September & 5 & II & 4 October \\
\hline & 25 September-8 October & 30 & III & 18 October \\
\hline & 9-22 October & 36 & IV & 3 November \\
\hline & 23 October-19 November & 29 & V & 21 November \\
\hline \multirow[t]{4}{*}{2008} & 15 September-13 October & 1 & $\mathrm{I}$ & 27 October \\
\hline & 14-27 October & 16 & II & 3 November \\
\hline & 28 October-10 November & 82 & III & 10 November \\
\hline & 11-24 November & 1 & IV & 25 November \\
\hline
\end{tabular}

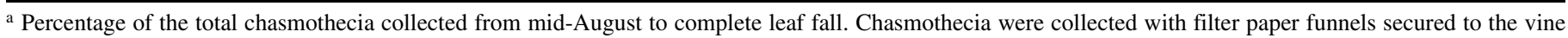
trunk; filter papers were replaced every 2 weeks, and chasmothecia were counted with a stereomicroscope.

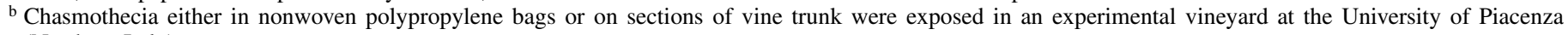
(Northern Italy). 
exceeding 0,5 , or $10^{\circ} \mathrm{C}$ (degree-days [DD]). In a preliminary analysis, the following equations were used: logistic, monomolecular, and Gompertz, in the forms shown by Campbell and Madden (6). The equation parameters were estimated using the nonlinear regression procedure of SPSS (ver. 15, SPSS Inc.), which minimizes the residual sums of squares using the Marquardt algorithm. The magnitude of the standard errors of the model parameters, coefficient of determination adjusted for the degree of freedom $\left(R^{2}\right)$, and the magnitude and distribution of residues were used to evaluate the goodness-of-fit. In particular, the following indexes were considered: NS model-efficacy, index of agreement (W), root mean square error (RMSE), model efficiency (EF), and coefficient of residual mass (CRM) (38). NS $=1$ and $\mathrm{W}=1$ represent a perfect fit; RMSE (which is the square root of the mean square error and represents the average distance of real data from the fitted line) should be as low as possible; when EF (that is an indicator of the extent to which outliers are affecting the model evaluation) increases toward 1 , the fit of the simulated process increases; and CRM (that measures the tendency of the model to overestimate or underestimate the measured values) should be close to 0 (38). Because the best fits were obtained using the equation of Gompertz in the form $y=100 \times \exp [-a \times \exp (-b \times$ $x$ )], with $x=\mathrm{DD}$ (base $10^{\circ} \mathrm{C}$ ), results of the other equations are not shown in this work. In the Gompertz equation, $a$ is the parameter accounting for the lag of the progress curve and $b$ is the rate parameter.

Ascospore discharge. Ascospore discharge was determined with silicone-coated slides that were placed near the vine trunk sections holding the chasmothecia. Slides $(26$ by $76 \mathrm{~mm}$ ) were positioned $\approx 3 \mathrm{~cm}$ from the bark, at $45^{\circ}$ (Fig. 1). Slides were replaced at 7-day intervals (at 10:00 h) beginning from the time when chasmothecia on the trunk sections were exposed to late June of the following year; four replicate slides were used for each ascocarp cohort in each sample. E. necator ascospores were counted by examining the slides microscopically $(\times 250$ magnification) after application of lactophenol; four equidistant transects across the long axis of the slide were scanned at 25 regular intervals, so that 100 fields of vision per slide were examined. Spore numbers were corrected for the proportion of the slide examined and expressed as ascospores caught per square centimeter over the period of exposure.

\section{RESULTS}

Developmental stage of chasmothecia. In 2005, chasmothecia were first collected in the funnel traps between 27 August and 12 September. These chasmothecia, which were $9 \%$ of those trapped over the entire period (i.e., mid-August to complete leaf fall), were grouped with those collected between 13 and 26 September to form cohort I; this cohort was exposed to the environment in the experimental vineyard on 13 October (Table 1). Two other cohorts were formed in 2005 and were composed of ascocarps collected until 7 November; no chasmothecia were collected after this date. In 2006, collection of chasmothecia began between 3 and 19 September and stopped in mid-November; five cohorts of chasmothecia were formed (Table 1). In 2007, a small number of chasmothecia were collected between 14 and 28 August and between 29 August and 10 September (0.3 and $0.4 \%$ of the seasonal ascocarps, respectively). Five cohorts were formed in 2007; the last chasmothecia were found in the funnel traps collected on 19 November (Table 1). In 2008, no chasmothecia were collected in August and very few chasmothecia were collected between 1 September and 13 October $(0.01 \%$ of the total chasmothecia in both periods); these were all grouped in cohort I of 2008. Most $(82 \%)$ of the total chasmothecia in 2008 were collected between 28 October and 10 November, which formed cohort III (Table 1).

Regardless of the season (in this context, a season starts with ascocarp dispersal in fall and ends in late June of the next year) and the cohort, the percentage of chasmothecia with mature ascospores decreased over the season, reached a minimum between late February and mid-March, and then increased slightly (Fig. 2), with the exception of spring 2009, when no chasmothecia with mature ascospores were found after late March (Fig. 2D). Regardless of the year, no chasmothecia contained mature ascospores after mid- to late May (Fig. 2). All the chasmothecia with mature ascospores were viable. The contribution of any cohort to the total chasmothecia with mature ascospores found in a season was generally similar. In 2005-06, for instance, the sum over the different samples of the chasmothecia with mature ascospores belonging to cohorts I, II, and III accounted for 34, 36, and 30\% of the total chasmothecia with mature ascospores, respectively (Fig. 2A); in 2006-07, the five cohorts accounted for 23, 25, 20, 15 , and $17 \%$, respectively (Fig. 2B). Regardless of the season, all cohorts contained some chasmothecia that contained mature ascospores after bud break (Fig. 2).

In the period before complete leaf fall, $34 \%$ of the total chasmothecia collected in the season contained mature ascospores, $48 \%$ contained immature ascospores, and $18 \%$ were empty (Fig. 3 ). Between leaf fall and bud break, the percentage of chasmothecia with both mature and immature ascospores decreased and, between bud break and the end of June, $<2 \%$ of the total chasmothecia contained mature ascospores. After bud break, $>70 \%$ of the chasmothecia were empty (Fig. 3).

Dynamics of mature ascospores in spring. Mature ascospores were first observed in early March in 2006 and 2008 and after mid-March in 2007 (Fig. 4A); in 2009, no mature ascospores were found from late March to late June. In both 2006 and 2008, mature ascospores were already present before bud break; in total, these ascospores represented $8 \%$ of the total ascospores found during the years. Numbers of mature ascospores increased over time and peaked in the second half of April or in early May, depending on the year; in that period, vines were between bud break and bloom (Fig. 4A). Afterward, numbers decreased and no mature ascospores were found after mid- to late May, depending on the year. In all, $\approx 10 \%$ of total ascospores were found after bloom. Therefore, most $(82 \%)$ of the mature ascospores were found between bud break and bloom.

The best fit of the cumulative percentage of mature ascospores was obtained by using DD (base temperature $10^{\circ} \mathrm{C}$ ) as the independent variable in a Gompertz equation (Fig. 4B), in which parameter estimates and corresponding standard errors were $a=$ $1.95 \pm 0.188, b=1.91 \pm 0.293$, and $R^{2}=0.92$. The analysis of residuals gave the following results: $\mathrm{NS}=0.91, \mathrm{~W}=0.98$, $\mathrm{RMSE}=10.9, \mathrm{EF}=0.91$, and $\mathrm{CRM}=0.05$. Therefore, the goodness-of-fit may be considered high. Less satisfactory results were

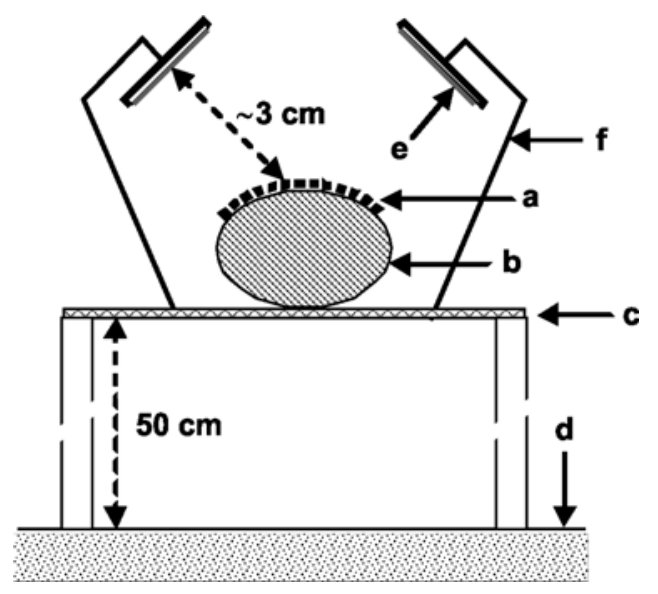

Fig. 1. Schematic representation of the method used for trapping Erysiphe necator ascospores: chasmothecia (a) were arranged on a vine trunk piece (b) fixed onto a metal net (c) at $50 \mathrm{~cm}$ above the soil (d). Ascospores were trapped on silicone-coated slides (e) that were fixed to metallic supports (f). 
obtained using the number of days or DD with base temperature of 0 or $5^{\circ} \mathrm{C}$ in logistic, monomolecular, or Gompertz equations (data not shown).

Ascospore discharge. In total, 147 trapping periods were considered over the four seasons. The total number of ascospores trapped were 16,800 in $2005-06,6,000$ in 2006-07, 25,400 in 2007-08, and 9,400 in 2008-09. The percentage of the ascospores trapped (relative to the total number trapped in the season) changed with time of year. In $2005-06,31 \%$ of the ascospores were trapped before leaf fall, $7 \%$ in winter, and $62 \%$ after bud beak (29\% between bud break and bloom, 33\% after bloom). In 2006-07, the ascospores trapped before leaf fall increased to $74 \%$ and, in 2007-08 they decreased to 19\%; because no or very few ascospores were trapped in winter, $26 \%$ and $81 \%$ of the ascospores were then trapped after bud break in 2006-07 and 200708, respectively. In 2008-09, all ascospores were trapped before leaf fall. Across all seasons, $56 \%$ of the total ascospores were caught before complete leaf fall, $2 \%$ were trapped from leaf fall to bud break, $26 \%$ from bud break to bloom, and $16 \%$ between bloom and the end of June (Fig. 5).

The time when chasmothecia were dispersed in fall did not influence the number of ascospores trapped after bud break in the next spring or their temporal trapping pattern (Fig. 6). In 2007,

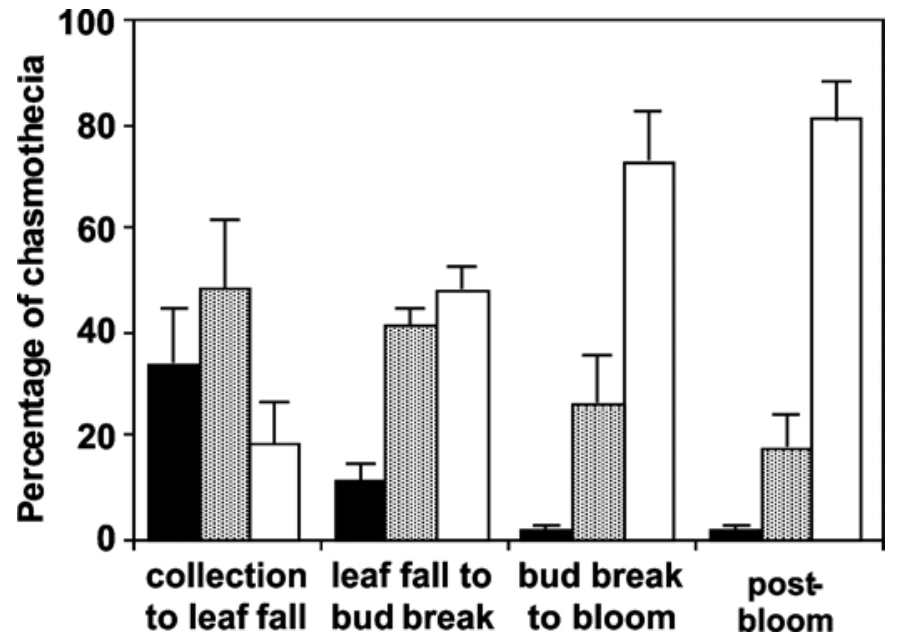

Fig. 3. Percentage of Erysiphe necator chasmothecia that contained mature ascospores (black bars) or immature ascospores (shadow bars) or were empty (white bars) within different periods between collection of chasmothecia and post-bloom of the next year. Bars are averages of the collections made in 2005 to 2008, while whiskers show the standard error.

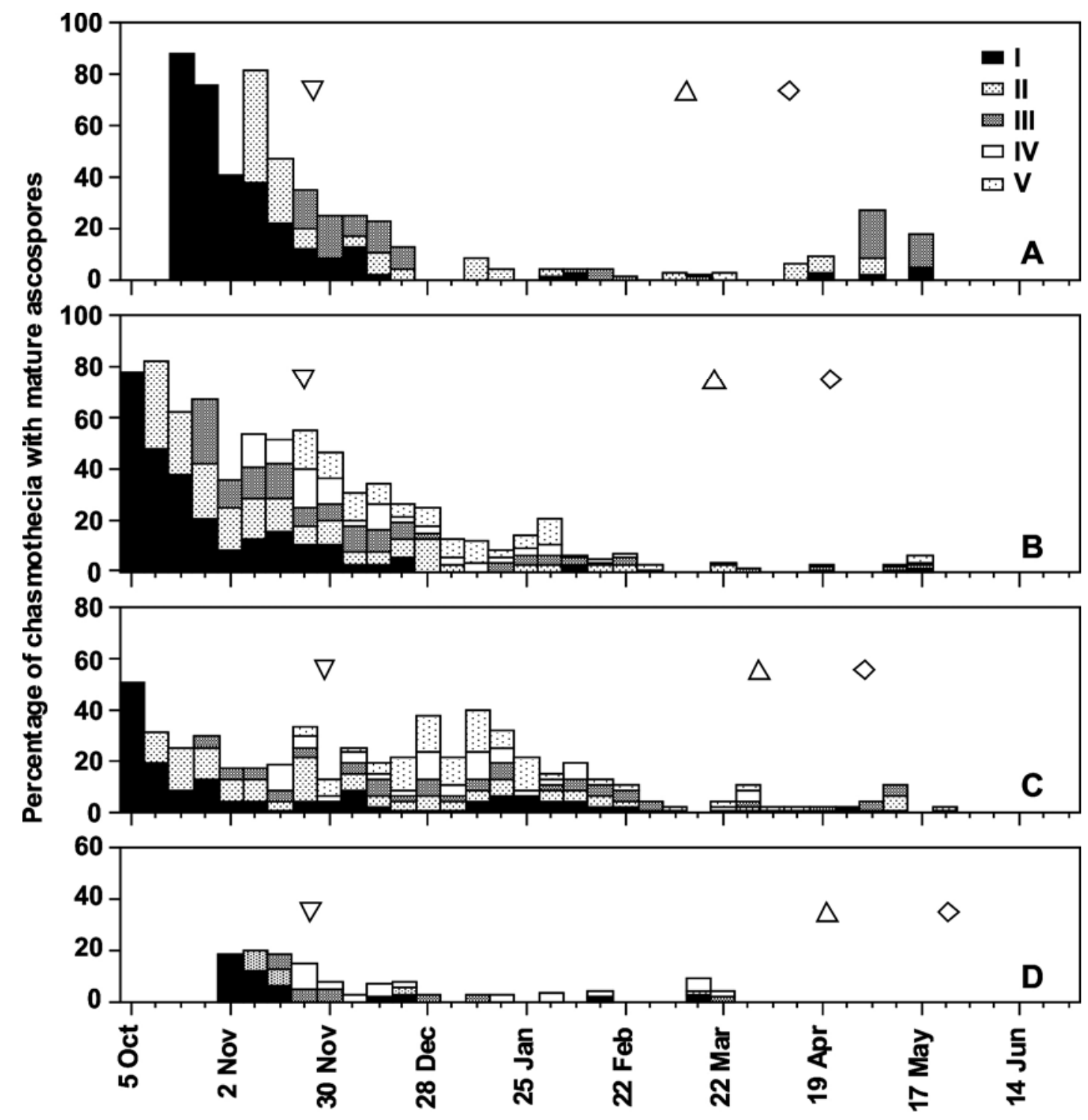

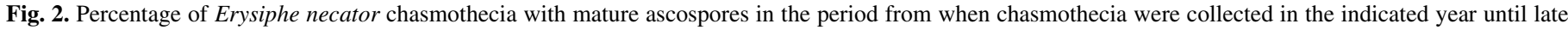

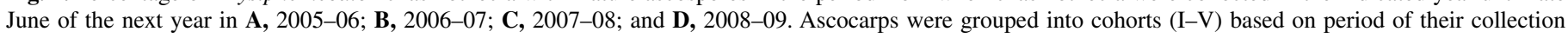
(Table 1). Symbols $\nabla, \Delta$, and $\diamond$ show complete leaf fall, bud break, and bloom, respectively. 
for instance, the numbers of ascospores released after bud break by the five cohorts of chasmothecia formed in autumn 2006 were not significantly different $(P=0.593)$ and accounted for 22,17 , 20,7 , and $34 \%$ of the total ascospores trapped after bud break, respectively (Fig. 6B). For all these cohorts, ascospores were trapped in 7 of the 15 trapping periods when spore traps were

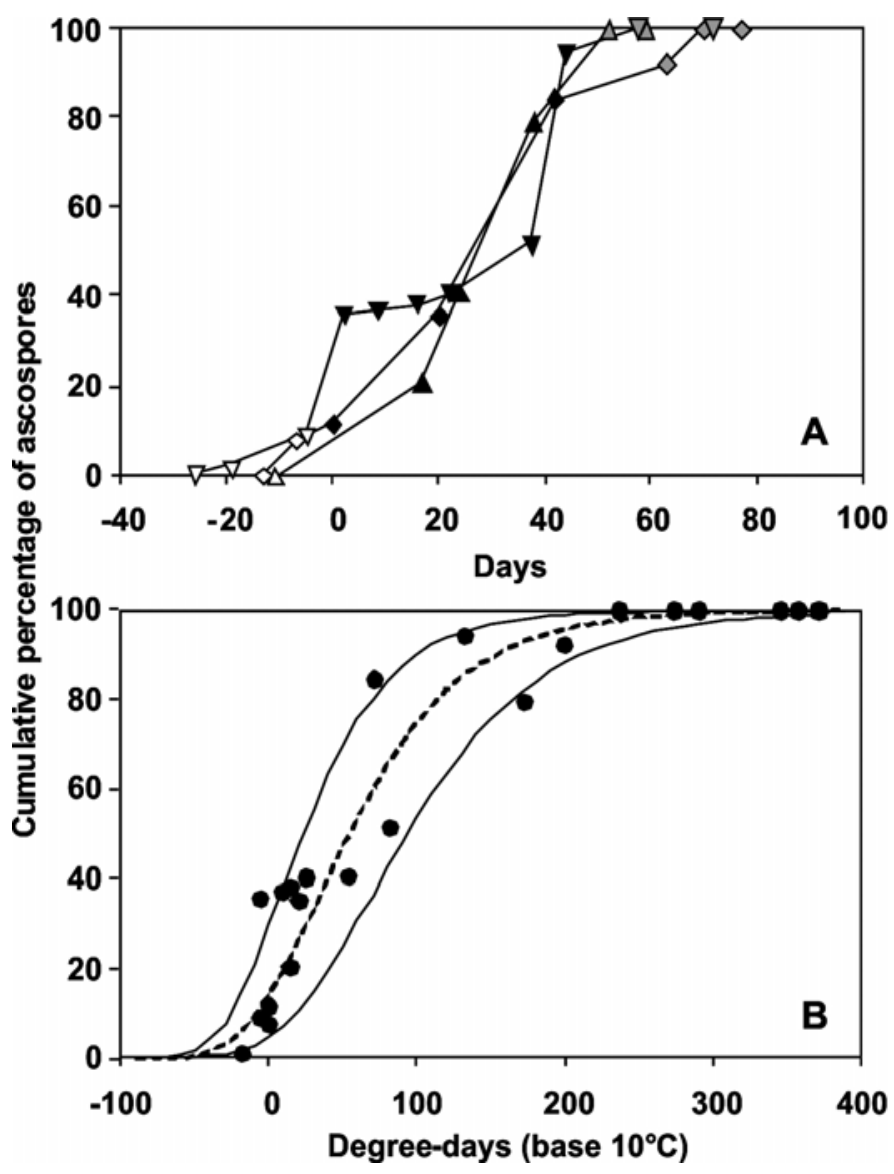

Fig. 4. Cumulative percentage of mature ascospores found in Erysiphe necator chasmothecia between late February to late June in 2006 to 2008. A, Time is expressed in days before or after bud break of $2006(\bullet), 2007(\boldsymbol{\Delta})$, and 2008 $(\boldsymbol{\nabla})$; symbols are white before bud break, black from bud break to bloom, and gray after bloom. B, Time is expressed in degree-days (base $10^{\circ} \mathrm{C}$ ) accumulated before or after bud break; curves fit the 3-year data (O) following a Gompertz equation (---) with the proper $95 \%$ confidence bands (...). Data of 2009 are not shown because no mature ascospores were found from late March to late June.

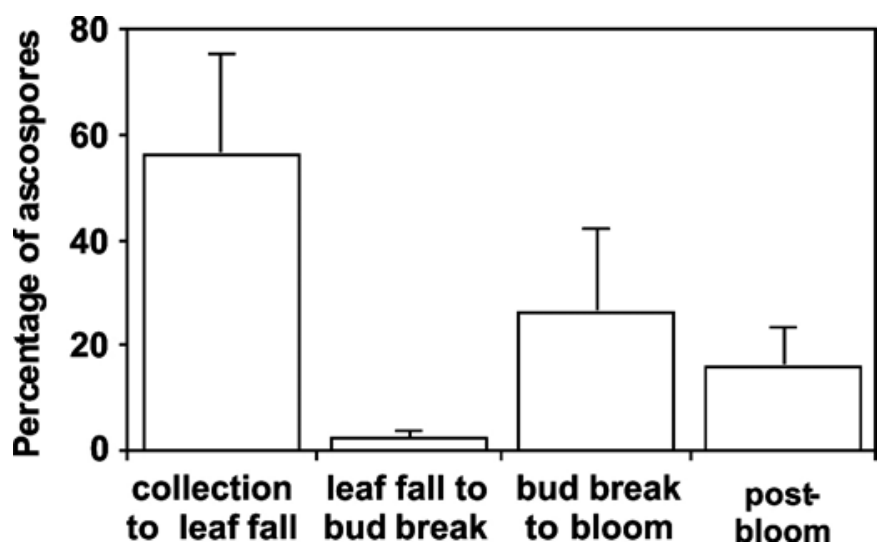

Fig. 5. Percentage of the Erysiphe necator ascospores trapped in different periods between collection of chasmothecia and post-bloom of the next year. Ascospores were trapped with silicone-coated microscope slides placed over chasmothecia arranged on vine bark sections. Bars are averages of the trappings made in 2005 to 2008, while whiskers show the standard error. exposed after bud break, with a similar pattern (Fig. 6B). The same was true for the three cohorts formed in 2005 (Fig. 6A) and the five cohorts formed in 2007 (Fig. 6C). In 2009, no ascospores were trapped after bud break (data not shown).

Relationship between weather and ascospore discharge. Ascospores were trapped in 53 of the 147 trapping periods (36\% of the periods); 48 (91\%) of these periods with ascospores had rain $(0.4$ to $86.8 \mathrm{~mm})$, and the average temperature of the period ranged from -2.1 to $23.3^{\circ} \mathrm{C}$ (Fig. 7). In 11 periods with ascospores, rain was $<2.5 \mathrm{~mm}$; these periods ended on 18 and 25 November 2005, 7 February 2006, 7 March 2006, and 18 April 2006 (Fig. 7A); 20 October 2006 (Fig. 7B); and 8 November 2007, 15 November 2007, 22 November 2007, 20 March 2007, and 8 May 2008 (Fig. 7C). Ascospores trapped during these periods with light rain accounted for $7 \%$ of the total ascospores.

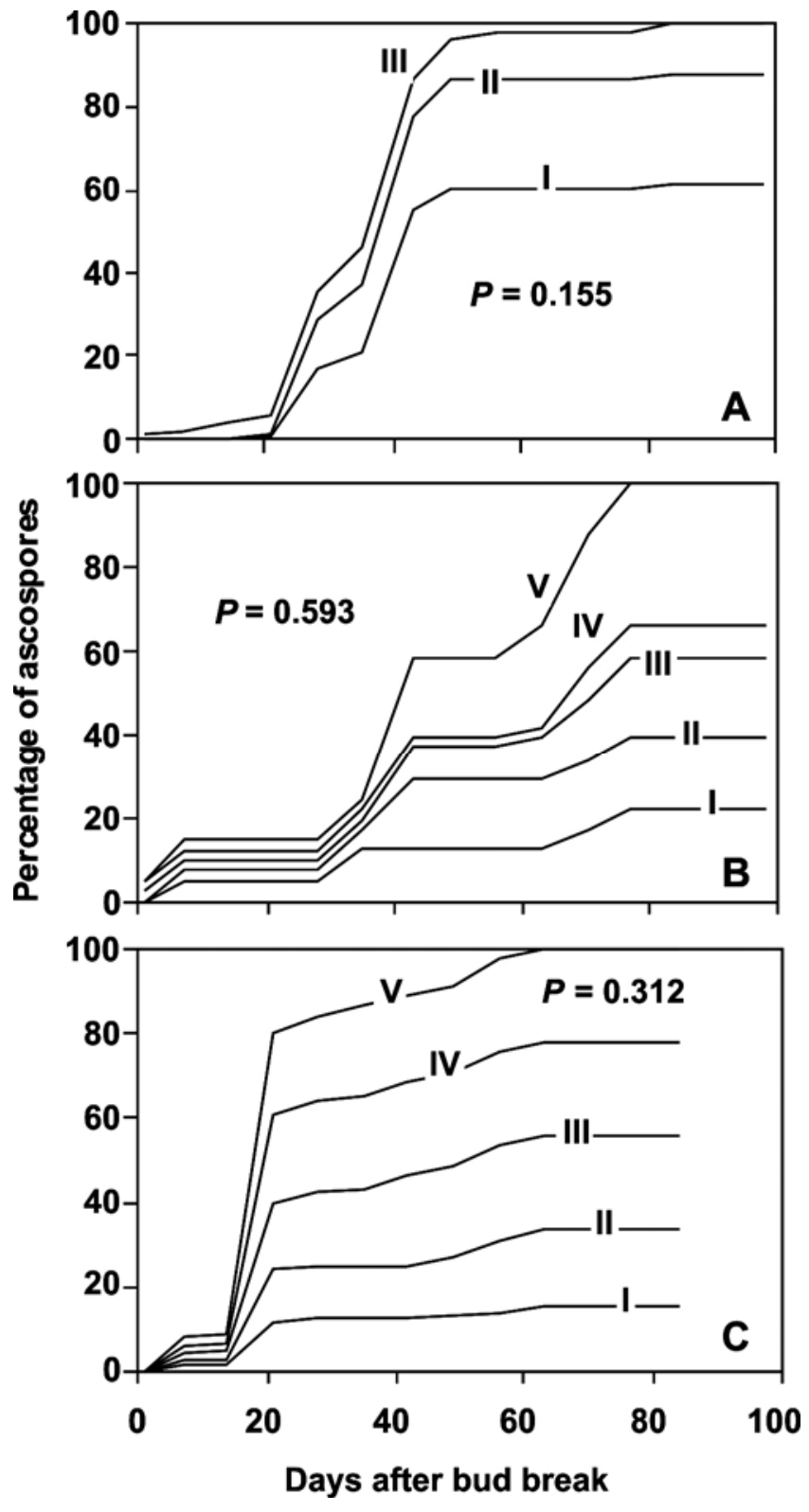

Fig. 6. Cumulative percentage of the Erysiphe necator ascospores trapped after bud break in A, 2006; B, 2007; and C, 2008. Ascospores were trapped with silicone-coated microscope slides placed over chasmothecia arranged on vine bark sections. Ascospores were grouped into cohorts (I to V) based on the period when chasmothecia were collected (Table 1). $P$ is the probability of the differences between cohorts in each year; $P$ was calculated by performing an analysis of variance on the arcsin transformation of the cumulative percentages at the end of the trapping period. 
In seven periods with ascospores, the average temperature was $<4^{\circ} \mathrm{C}$, which is the lowest temperature for ascocarp dehiscence (17); this always occurred before bud break of vines, from late November 2005 to mid-December 2005, and in January and
February 2006 (Fig. 7A). Ascospores trapped during these lowtemperature periods accounted for $2.1 \%$ of the total ascospores. In five of these periods, there were at least $4 \mathrm{~h}$ with rain and temperatures of 4.9 to $7.9^{\circ} \mathrm{C}$. In contrast, in the trapping period 25

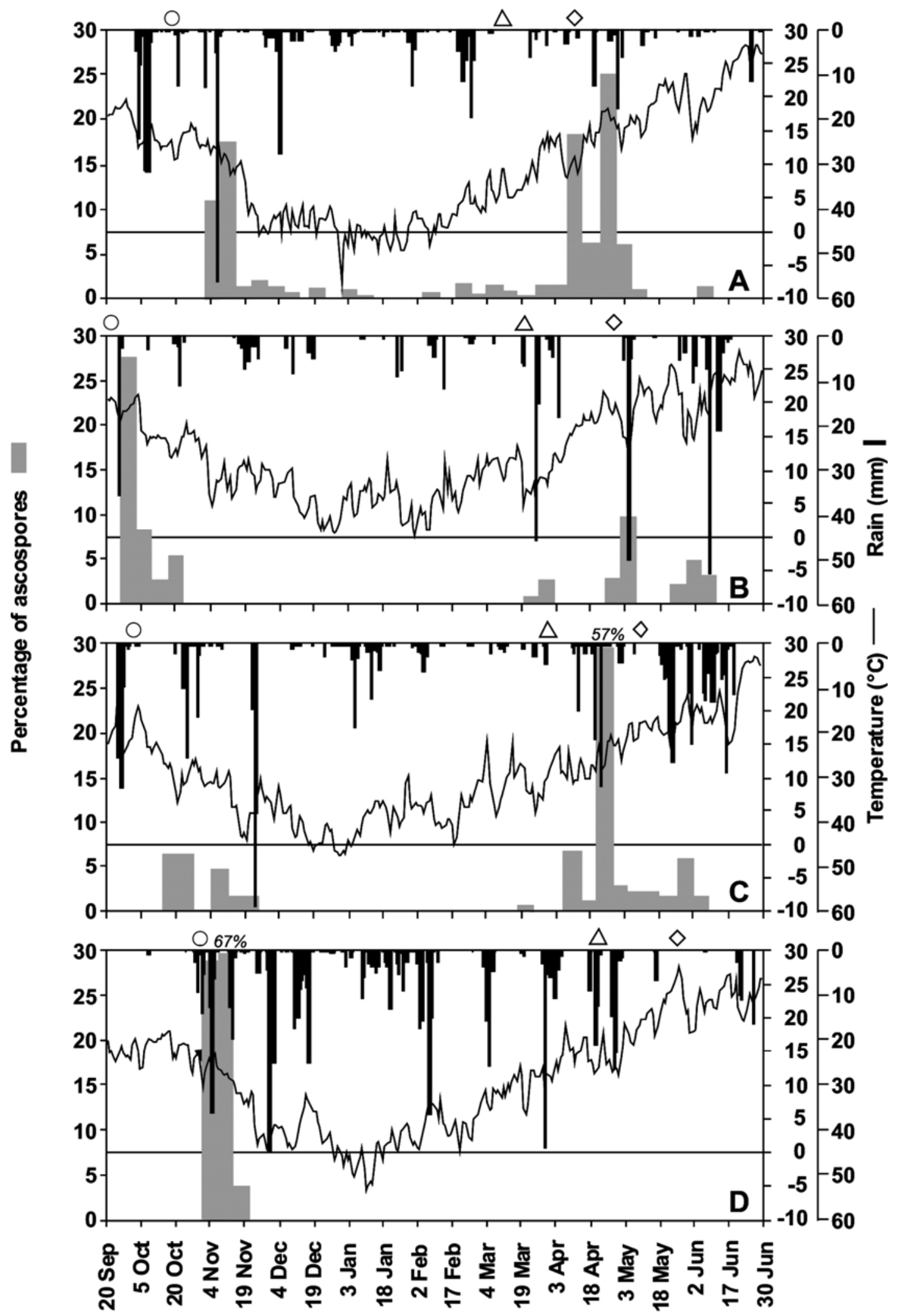

Fig. 7. Percentage of Erysiphe necator ascospores trapped at weekly intervals in the period from when chasmothecia were collected in the indicated year until late June of the next year for A, 2005-06; B, 2006-07; C, 2007-08; and D, 2008-09. Ascospores were trapped with silicone-coated microscope slides placed over chasmothecia arranged on vine bark sections; gray bars represent the relative proportion of the ascospores trapped in a week compared with total trappings. Black bars show rainfall and dotted lines air temperature. Symbols $\bigcirc, \Delta$, and $\diamond$ show time when the first chasmothecia were exposed on vine bark, bud break, and bloom, respectively. Numerical values in $\mathrm{C}$ an $\mathrm{D}$ represent percentages of ascospores exceeding the maximum value of the axis. 
November to 2 December 2005, all the hours with temperature $\geq 4^{\circ} \mathrm{C}$ were dry; on 2 December, there were $5 \mathrm{~h}$ with $8.8 \mathrm{~mm}$ of rain but the average temperature was $2.9^{\circ} \mathrm{C}$. Similarly, in the period 19 to 27 December 2005, the most favorable period for ascocarp dehiscence was on 25 December, which had $6 \mathrm{~h}$ with $9 \mathrm{~mm}$ of rain and an average temperature of $3.3^{\circ} \mathrm{C}$.

Ascospores were trapped in five periods with no rain: 7 to 14 March 2006; 29 September to 6 October 2006 (Fig. 7A); 20 to 27 April 2007 (Fig. 7B); and 11 to 18 October 2007 and 8 to 15 May 2008 (Fig. 7C). The ascospores trapped in these periods accounted for $4 \%$ of the total ascospores. In three of these cases, several hours of wetness due to dew occurred during the trapping period. On 11 to 18 October 2007, there were numerous periods of wetness, the longest one on 17 to 18 October, with $13 \mathrm{~h}$ of wetness at $10.3^{\circ} \mathrm{C}$ (Fig. 8A). On 2 October 2006, there were $11 \mathrm{~h}$ of wetness at $17.7^{\circ} \mathrm{C}$ (data not shown) and, on 20 to 21 April 2007 , there were $8 \mathrm{~h}$ of wetness at $13.9^{\circ} \mathrm{C}$ (Fig. $8 \mathrm{~B}$ ). In other cases, the trapping period was dry: on 7 to 14 March 2006, there were only $3.5 \mathrm{~h}$ of wetness at $4.0^{\circ} \mathrm{C}$ on 11 March (Fig. 8C); in the whole period 8 to 15 May 2008, there were only 3.5 h of wetness in total (data not shown).

\section{DISCUSSION}

Chasmothecia of E. necator develop on the infected host tissues of grapevines late in the growing season. Mature chasmothecia (i.e., ascocarps with necrosis of the anchorage hypae) (16) are repeatedly dispersed whenever there is rain. At that time, chasmothecia already contain viable and infectious ascospores $(10,14$, $25,27)$. Most chasmothecia that land on the bark of vines remain viable until the following spring, whereas most chasmothecia that land on the leaf litter or in the soil die in the winter $(9,16,25)$.

The period of ascocarp dispersal began in mid-August to midSeptember, depending on the year, and finished in mid- to late November, when leaf fall was complete. In this period, $34 \%$ of the total chasmothecia collected had mature ascospores, $48 \%$ had immature ascospores, and $18 \%$ were empty. In the same period, ascospores were repeatedly trapped by the spore traps; 19 to $74 \%$ of the total ascospores were trapped before leaf fall, depending on the year. In the period between complete leaf fall and bud break, chasmothecia with mature ascospores were also recovered (11\% of the total chasmothecia), and small numbers of ascospores ( $<2 \%$ of the total ascospores) were trapped. Empty chasmothecia may be then regarded as ascocarps that had already ejected ascospores. In P. aphanis, the strawberry (Fragaria vesca L.) powdery mildew fungus, once ascospore release has taken place, the ascocarps close and, at $\times 20$ magnification, often cannot be distinguished from intact and nondehiscent chasmothecia (15).

The ability of E. necator ascocarps to mature and release ascospores late in the grape-growing season and also when grapevines are dormant has been previously suggested in California (23) and documented in southern Australia (20). In contrast, ascospores that have not overwintered are rarely released from chasmothecia in New York State $(17,39)$, even though they are already physiologically mature in early autumn (i.e., they are able to germinate) (18). Gee et al. (20) related the different patterns in southern Australia and New York to differences in the accumulation of DD following chasmothecia initiation (greater in Australia than in New York) and to the temperature regime in winter (milder in Australia than in New York). Chasmothecia require an accumulation of $\approx 200 \mathrm{DD}$ (base $10^{\circ} \mathrm{C}$ ) from formation until morphological maturation (17). In New York, this requirement is usually met in August, and there is insufficient heat accumulation after mid-September to mature chasmothecia produced in the current year by leaf fall (37); DD from August to the average date of leaf fall (i.e., 31 October) (37) is $\approx 550$ DD (using climate data of Rochester from http://weather.msn.com/). At the site of this study, 350 to $400 \mathrm{DD}$ were still available after mid-September, and DD from August to leaf fall was 800 to 920, depending on the year. Our data from Northern Italy strongly support the hypothesis of Gee et al. (20).

The epidemiological significance of functional chasmothecia (chasmothecia that release ascospores) late in powdery mildew epidemics (in late summer and autumn) has not been previously investigated. Their presence could increase the probability that fungal colonies form and that new chasmothecia develop. Regarding the formation of colonies, asexual sporulation ceases in powdery mildew colonies where ascocarps are forming, probably as a prerequisite for the initiation of chasmothecia (12). The production of ascospores late in the season might compensate for this reduction in spores that could form new colonies. Ascospores are also more suited than conidia to late summer and autumn conditions of Northern Italy, which are characterized by diminishing temperatures and increasing rainfall and moisture. Both germination and infection at low temperature are higher for ascospores than for conidia; at $10^{\circ} \mathrm{C}$, for instance, $90 \%$ of the ascospores germinate and $\approx 20 \%$ form appressoria (18), while germination of conidia is only $\approx 5 \%(1,11)$. In addition, direct contact of conidia with water frequently causes them to burst or fail to form infection structures (2) whereas ascospore germination is enhanced by saturated atmospheres and contact with free water (18). Regarding the formation of chasmothecia, rate and numbers of chasmothecia $(19,35)$, as well as numbers of ascospores discharged in the next spring and their infectivity (20), all depend on the particular combination of isolates that form chasmothecia. Therefore, an increased probability that new colonies form as a result of lateseason ascospore release would likely be accompanied by an increased probability of mating between different strains. All of these possible roles of late-season ascospores require investigation.

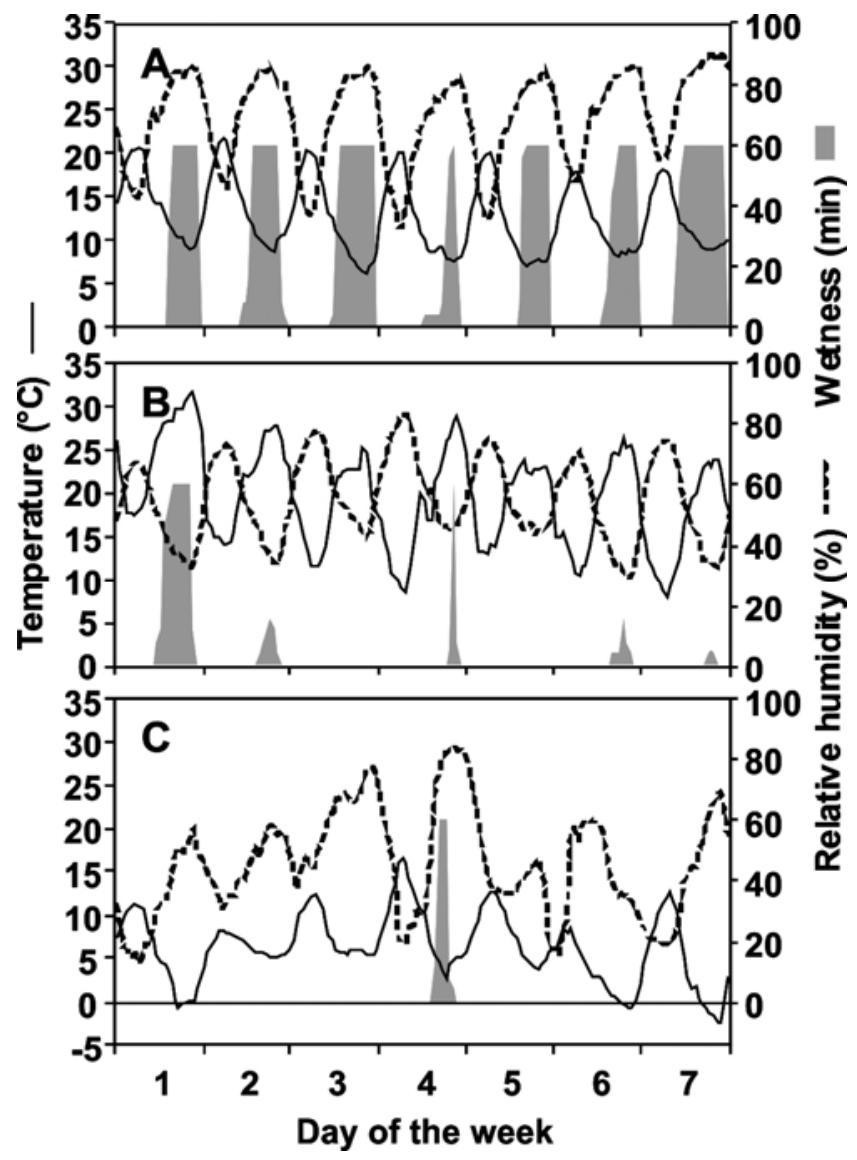

Fig. 8. Air temperature, relative humidity, and duration of wetness in 3 weeks when Erysiphe necator ascospores were trapped in the absence of rain on $\mathbf{A}$, 12 to 18 October 2007; B, 21 to 27 April 2007; and C, 7 to 14 March 2006. 
As reported previously for other geographic areas $(10,21$, 25,39 ), the number of viable chasmothecia diminished over time. Under the conditions of this work, $\approx 5 \%$ of the total chasmothecia observed contained mature ascospores after bud break; these ascocarps discharged $\approx 42 \%$ of the total ascospores trapped over the 4-year period, during several discharge events. Therefore, the ascospore supply in spring may be considered a significant and repeated source of inoculum for primary infection after bud break. In this work, the abundance of mature ascospores in chasmothecia was expressed as a function of DD (base temperature $10^{\circ} \mathrm{C}$ ) accumulated before and after bud break through a Gompertz equation that accounted for $92 \%$ of the observed variability. Based on this equation, $90 \%$ of the ascospores were mature when 153 DD (confidence interval 100 to 210 DD) had accumulated after bud break. Pearson and Gadoury (39) found that ascospore release continued for 6 to 10 weeks and speculated that temperature may be one environmental factor that determines the rate of ascospore maturation and the time of ascospore release. Moyer et al. (36) found that, once initiated, the ascospore supply was often depleted within 100 DD. If this relationship is confirmed with other, independent data, the Gompertz equation reported here could be used to estimate potential ascospore availability in a vineyard when suitable conditions for ascospore discharge occur.

Under the conditions of this work, some ascospores were mature and became airborne before bud break. In-vineyard ascospore discharge before bud break was also occasionally found in New York (39) and in southern Australia (20) but not in Washington State $(13,21)$ or in the Bordeaux area of France (31). This discrepancy probably results from the fortuitous occurrence of suitable conditions for ascospore discharge before bud break in some of the abovementioned study sites. Moyer et al. (36) recently showed that, when artificially subjected to conditions conducive for dehiscence, chasmothecia release ascospores largely before bud break; these authors speculated that early discharge under vineyard conditions may depend on the occurrence of rain events suitable for ascocarp dehiscence. Moyer et al. (36) also documented that, in several site-year combinations, ascospore release was nearly complete before local bud break of grapevines. The same occurred in 2009 in the current study.

The discharge of ascospores has been related to rainy periods with cumulative rainfall $>2 \mathrm{~mm}(31)$ or $>2.5 \mathrm{~mm}(17,39)$, which initiated a wetting period $>2.5 \mathrm{~h} \mathrm{(31)}$, and with temperatures $>8^{\circ} \mathrm{C}$ (31); at $4^{\circ} \mathrm{C}$, ascocarp dehiscence is reduced by $80 \%$ compared with the optimal temperature of $25^{\circ} \mathrm{C}$ (17). In this work, $\approx 90 \%$ of the ascospores were trapped during periods when these minimum requirements for ascospore discharge occurred. However, a few ascospores were airborne when there was $<2.0$ or $2.5 \mathrm{~mm}$ of rainfall and, occasionally, in wet periods of $\geq 3.5 \mathrm{~h}$ that were not initiated by rain. In addition, in some periods before bud break of vines, ascospores were airborne when the temperature was $<4^{\circ} \mathrm{C}$.

It is generally thought that, during rain, chasmothecia are soaked in water and this is necessary for ascocarp dehiscence (30). Wetting in the absence of rain, however, can also soak the chasmothecia. Gadoury and Pearson (17) obtained dehiscence by placing chasmothecia on a moist filter paper for a minimum of $2 \mathrm{~h}$. In our experiments, a sufficient soaking of chasmothecia on the vine bark may have been provided by light rainfall (i.e., $<2 \mathrm{~mm}$ ) or by a wet period not triggered by rainfall. No previous information exists about the rate of ascocarp dehiscence at $<4^{\circ} \mathrm{C}$ $(17,30)$.

The age-related behavior of the ascocarp population in $E$. necator has not been previously studied. In this work, chasmothecia were collected at different times to generate three to five cohorts of chasmothecia per year. All collections contained ascocarps that were able to release ascospores in autumn, survive the winter, and release viable ascospores in the next spring. Neither the number of ascospores released in the next spring nor their temporal release pattern was influenced by the time when the chasmothecia were dispersed. In S. mors-uvae, the timing of ascospore release in spring depends on the timing of ascocarp formation in the previous season (29). Our results indicate that this is not the case with E. necator (i.e., from an epidemiological point of view, E. necator chasmothecia may be considered uniform regardless of the exact time of their development in the previous season).

Effective management of grape powdery mildew is facilitated by a basic understanding of the epidemiology of the disease. Control of powdery mildew is traditionally based on the management of secondary infections. For this purpose, some mathematical models have been developed for simulating epidemics caused by asexual (secondary) infections $(8,22,32,41)$ or evaluating the risk of powdery mildew infection and, thereby, scheduling fungicide applications. Recently, a dynamic model for ascosporic (primary) infections has been proposed as a tool for a new, early-season strategy that reduces establishment of the disease and, thereby, reduces the probability of powdery mildew epidemics later in the summer (5). Results from the present work provide additional information about ascopore maturation and release over time as influenced by environmental conditions. These results have also raised questions about the possible role of late-season ascospores in the vineyard. If research determines that late-season ascopores contribute to disease incidence and severity, an efficient control strategy should include post-harvest sprays to control late-season powdery mildew development and, consequently, to reduce production of ascocarps. Sprays during the dormant period may also be useful in suppressing the overwintering population of the fungus.

\section{LITERATURE CITED}

1. Bendek, C. E., Campbell, P. A., Torres, R., Donoso, A., and Latorre, B. A. 2007. The risk assessment index in grape powdery mildew control decisions and the effect of temperature and humidity on conidial germination of Erysiphe necator. Span. J. Agric. Res. 5:522-532.

2. Blaich, R., Heintz, C., and Wind, R. 1989. Studies on conidial germination and initial growth of the grapevine powdery mildew Uncinula necator on artificial substrates. Appl. Microbiol. Biotechnol. 30:415-421.

3. Braun, U., Cook, R. T. A., Inman, A. J., and Shin, H. D. 2002. The taxonomy of the powdery mildew fungi. Pages 13-55 in: The Powdery Mildews: A Comprehensive Treatise. R. R. Bélanger, W. R. Bushnell, A. J. Dik, and T. L. W. Carver, eds. American Phytopathological Society Press, St. Paul, MN.

4. Caffi, T., Cavagna, S., and Rossi, V. 2008. Ascospore maturation and discharge in Erysiphe necator. J. Plant Pathol. 90 (Suppl. 2):157.

5. Caffi, T., and Rossi, V. 2009. A Mechanistic model for infection of grapevines by ascospores of Erysiphe necator. Pages 23-25, in: Proc. 10th Int. Epidemiol. Workshop, Geneva, NY.

6. Campbell, C. L., and Madden, L. V. 1990. Introduction to Plant Disease Epidemiology. Wiley, New York.

7. Carisse, O., Bacon, R., Lefebvre, A., and Lessard, K. 2009. A degree-day model to initiate fungicide spray programs for management of grape powdery mildew (Erysiphe necator). Can. J. Plant Pathol. 31:186-194.

8. Chellemi, D. O., and Marois, J. J. 1991. Development of a demographic growth model for Uncinula necator by using a microcomputer spreadsheet program. Phytopathology 81:250-254.

9. Cortesi, P., Bisiach, M., Ricciolini, M., and Gadoury, D. M. 1997. Cleistothecia of Uncinula necator-an additional source of inoculum in Italian vineyards. Plant Dis. 81:922-926.

10. Cortesi, P., Gadoury, D. M., Seem, R. C., and Pearson, R. C. 1995. Distribution and retention of cleistothecia of Uncinula necator on the bark of grapevines. Plant Dis. 79:15-19.

11. Delp, C. J. 1954. Effect of temperature and humidity on the grape powdery mildew fungus. Phytopathology 44:615-626.

12. Evans, K. J., Scott, E. S., and Whisson, D. L. 1997. Heterothallism among South Australian clonal lines of Uncinula necator. Australas. Plant Pathol. 26:10-20.

13. Falacy, J. S., Grove, G. G., Mahaffee, W. F., Galloway, H., Glawe, D. A., Larsen, R. C., and Vandemark, G. 2007. Detection of Erysiphe necator in air samples using the polymerase chain reaction and species-specific primers. Phytopathology 97:1290-1297.

14. Füzi, I. 1999. The occurrence of cleistothecial form of grape powdery 
mildew (Uncinula necator/Schw./Burr.) and the process of formation of cleistothecia in Trans-Danubian vineyards. Novenyvedelem 35:137-145.

15. Gadoury, D. M., Asalf, B., Heidenreich, M. C., Herrero, M. L., Welser, M. J., Seem, R. C., Tronsmo, A. M., and Stensvand, A. 2010. Initiation, development, and survival of cleistothecia of Podosphaera aphanis and their role in the epidemiology of strawberry powdery mildew. Phytopathology 100:246-251.

16. Gadoury, D. M., and Pearson, R. C. 1988. Initiation, development, dispersal and survival of cleistothecia of Uncinula necator in New York vineyards. Phytopathology 78:1413-1421.

17. Gadoury, D. M., and Pearson, R. C. 1990. Ascocarp dehiscence and ascospore discharge in Uncinula necator. Phytopathology 80:393-401.

18. Gadoury, D. M., and Pearson, R. C. 1990. Germination of ascospores and infection of Vitis by Uncinula necator. Phytopathology 80:1198-1203.

19. Gadoury, D. M., and Pearson, R. C. 1991. Heterothallism and pathogenic specialization in Uncinula necator. Phytopathology 81:1287-1293.

20. Gee, L. M., Stummer, D. M., Gadoury, D. M., Biggins, L. T., and Scott, E. S. 2000. Maturation of cleistothecia of Uncinula necator (powdery mildew) and release of ascospores in southern Australia. Aust. J. Grape Wine Res. 6:13-20.

21. Grove, G. G. 2004. Perennation of Uncinula necator in vineyards of Eastern Washington. Plant Dis. 88:242-247.

22. Gubler, W. D., Rademacher, M. R., Vasquez, S. J., and Thomas, C. S. 1999. Control of Powdery Mildew using the UC Davis Powdery Mildew Risk Index. Published online by American Phytopathological Society, St. Paul, MN.

23. Gubler, W. D., Yema, H. L., Ouimette, D. G., and Bettiga, L. J. 1994. Resistance of Uncinula necator to DMI fungicides in California vines. Pages 19-25 in: Fungicide Resistance. S. Heany, D. Slawson, D. W. Hollomon, M. Smith, P. E. Russell, and D. W. Parry, eds. Br. Crop Prot. Counc. Monogr. No. 60.

24. Hajian, M., Zad, J., Tehrani, A. S., Okhovvat, M., and Safarnezhad, A. 2005. Effect of environmental conditions on release, germination and pathogenicity of ascospores in Uncinula necator, the casual agent of grape powdery mildew. Iran. J. Agric. Sci. 36:121-128.

25. Hajjeh, H., Miazzi, M., and Faretra, F. 2008. Overwintering of Erysiphe necator Schw. in southern Italy. J. Plant Pathol. 90:323-330.

26. Halleen, F., and Holz, G. 2000. Cleistothecia and flag shoots: sources of primary inoculum for grape powdery mildew in the Western Cape province, South Africa. S. Afr. J. Enol. Vitic. 21:66-70.

27. Hoffmann, P., Füzi, I., and Viranyi, F. 2007. Studying the sexual overwintering form of Erysiphe necator Schwein with laboratory methods. Novenyvedelem 43:265-272.

28. Hoffmann, P., and Virányi, F. 2007. The occurrence of cleistothecia of Erysiphe necator (grapevine powdery mildew) and their epidemiological significance in some vine-growing regions of Hungary. Acta Phytopathol. Entomol. Hung. 42:9-16.

29. Jackson, G. V. H., and Wheeler, B. E. J. 1974. Perennation of
Sphaerotheca mors-uvae as cleistocarps. Trans. Br. Mycol. Soc. 62:73-87.

30. Jailloux, F., Thind, T., and Clerjeau, M. 1998. Release, germination, and pathogenicity of ascospores of Uncinula necator under controlled conditions. Can. J. Bot. 76:777-781.

31. Jailloux, F., Willocquet, L., Chapuis, L., and Froidefond, G. 1999. Effect of weather factors on the release of ascospores of Uncinula necator, the cause of grape powdery mildew, in the Bordeaux region. Can. J. Bot. 77:1044-1051

32. Kast, W. K. 1995. A step by step risk analysis (SRA) used for planning sprays against powdery mildew (OiDiag-System). Vitic. Enol. Sci. 52:230-321.

33. Lovell, D. J., Powers, S. J., Welham, S. J., and Parker, S. R., 2004. A perspective on the measurement of time in plant disease epidemiology. Plant Pathol. 53:705-12.

34. Magarey, P. A., Gadoury, D. M., Emmet, R. W., Biggins, L. T., Clarke, K., Wachtel, M. F., Wicks, T. J., and Seem, R. C. 1997. Cleistothecia of Uncinula necator in Australia. Page 122 in: Proc. 2nd Int. Workshop Grapevine Downy Powdery Mildew Modelling, Freiburg, Germany.

35. Miazzi, M., Hajjeh, H., and Faretra, F. 2003. Observations on the population biology of the grape powdery mildew fungus Uncinula necator. J. Plant Pathol. 85:123-129.

36. Moyer, M. M., Gadoury, D. M., Wilcox, W. F., and Seem, R. C. 2008. Seasonal release of ascospores by Erysiphe necator. (Abstr.) Phytopathology 98:S109.

37. Moyer, M. M., Gadoury, D. M., Wilcox, W. F., and Seem, R. C. 2009. Understanding the relationship between weather and severity of powdery mildew (Erysiphe necator) on grapevine berries in New York State. Pages 104-105 in: Proc. 10th Int. Epidemiol. Workshop, Geneva, NY.

38. Nash, J. E., and Sutcliffe, J. V. 1970. River flow forecasting through conceptual models part I - a discussion of principles. J. Hydrol. 10:282-290.

39. Pearson, R. C., and Gadoury, D. M. 1987. Cleistothecia, the source of primary inoculum for grape powdery mildew in New York. Phytopathology 77:1509-1514.

40. Rossi, V., Caffi, T., and Legler, S. E. 2009. A model for maturation and dispersal of Erysiphe necator cleistothecia. Pages 138-139 in: Proc. 10th Int. Epidemiol. Workshop, Geneva, NY.

41. Sall, M. A. 1980. Epidemiology of grape powdery mildew: A model. Phytopathology 70:338-342.

42. Schnathorst, W. C. 1965. Environmental relationships in the powdery mildews. Annu. Rev. Phytopathol. 3:343-366.

43. Schneider, S., Kassemeyer, H. H., Blaich, R., Seem, R. C., and Gadoury, D. M. 1998. Cleistothecia as primary inoculum for grape powdery mildew in Germany. (Abstr.) Phytopathology 88:S79.

44. Smith, C. G. 1970. Production of powdery mildew cleistocarps in a controlled environment. Trans. Br. Mycol. Soc. 55:355-365.

45. Steinkellner, S., and Redl, H. 1998. Investigation into the development of cleistothecia of grape powdery mildew under Austrian vine growing conditions. Mitt. Klosterneuburg 48:17-24. 